2013

\title{
Factors Related to Recidivism for Youthful Offenders
}

Christopher A. Mallett

Follow this and additional works at: https://engagedscholarship.csuohio.edu/clsowo_facpub How does access to this work benefit you? Let us know!

Publisher's Statement

This is an Accepted Manuscript of an article published by Taylor \& Francis in Criminal Justice Studies on $10 \mathrm{Jul}$ 2012, available online: http://wwww.tandfonline.com/10.1080/

$1478601 X .2012 .705539$.

\section{Recommended Citation}

Mallett, Christopher A., "Factors Related to Recidivism for Youthful Offenders" (2013). Social Work Faculty Publications. 30.

https://engagedscholarship.csuohio.edu/clsowo_facpub/30

This Article is brought to you for free and open access by the School of Social Work at EngagedScholarship@CSU. It has been accepted for inclusion in Social Work Faculty Publications by an authorized administrator of EngagedScholarship@CSU. For more information, please contact library.es@csuohio.edu. 


\title{
Factors related to recidivism for youthful offenders
}

\author{
Christopher A. Mallett*, Miyuki Fukushima, Patricia Stoddard-Dare and \\ Linda Quinn
}

Cleveland State University, 2121 Euclid Avenue, \#CB324, Cleveland, OH 44115, USA

\begin{abstract}
Little is known about youth who were previously placed in a detention facility and what factors predict a subsequent recidivism to placement. This study of a two-county juvenile offender population (one urban and one rural) investigates what demographic, educational, mental health, substance dependence, and courtrelated variables predict recidivism to detention placement. Findings from logistic regression analysis indicate that seven variables significantly predict juvenile offenders' recidivism placement, some expected and some unexpected. Predictors that made recidivism more likely include youth with a previous conduct disorder diagnosis, a self-reported previous suicide attempt, age, and number of court offenses. Conversely, predictors that made recidivism less likely include race (Caucasian), a previous attention-deficit hyperactivity disorder diagnosis, and a misdemeanor conviction. These findings indicate that the use of a community-based suicide and mental health screening and referral approach may help to identify and assist these high-risk youth in receiving needed services prior to juvenile court involvement or during delinquency adjudication.
\end{abstract}

Keywords: recidivism; delinquency; youth; mental health; suicide

\section{Introduction}

Over the past two decades, the juvenile justice field has been intermittently shifting between a punitive and rehabilitative approach to dealing with youthful offenders, resulting from organized reformation activities by key stakeholders and progressive juvenile courts, and today's high cost of detainment and incarceration. Recently, poor juvenile court outcomes for many youthful offenders, particularly serious offenders, have influenced an incremental movement away from 'tough on crime' policies. Furthermore, the number of youth involved annually in the juvenile justice system nationwide, while trending downward in recent years, is still somewhat staggering - over 2.1 million arrests of youth under age 18 (Puzzanchera, 2009), 1.7 million delinquency cases (Knoll \& Sickmund, 2010), 350,000 youth held in detention centers (Holman \& Ziedenberg, 2006; Sickmund, 2008), and over 100,000 youth held in correctional facilities (Davis, Tsukida, Marchionna, \& Krisberg, 2008; Sickmund, 2009). This paper focuses on more serious youthful offenders who previously served time in a detention facility and then recidivate to detention center placement. This repeat detention experience does neither the youth nor the juvenile court systems much benefit, and is increasingly being recognized as detrimental to

*Corresponding author. Email: c.a.mallett@csuohio.edu 
the youth and the juvenile courts' public policy goals of youth accountability and maintaining safe communities. Thus, reducing recidivism is an important juvenile justice system priority (US Department of Justice, 2010).

\section{Background}

\section{Juvenile delinquency}

There exist many risk factors for juvenile justice system involvement and youth delinquency. These risks are related to the individual (early aggression, mental health problems, and substance abuse), family (inconsistent parenting and trauma), school (academic problems, educational deficits, and special education disabilities), and neighborhood (high levels of unemployment, residential instability, and family disruptions) (Bor, McGee, \& Fagan, 2004; Bursik \& Grasmick, 1993, 1995; Hawkins et al., 1998; Hay, Fortson, Hollist, Altheirmer, \& Schaible, 2006; Lynam, Moffitt, \& Stouthamer-Loeber, 1993; Mallett, 2011; Sampson, Raudenbush, \& Earls, 1997; Tremblay et al., 2004). In addition, a number of youth demographic factors have been consistently found to predict juvenile court supervision; hence, researchers usually control for their impact in their analysis. These factors include juveniles' age (older youth are more likely), gender (males are more likely, though females are increasing in numbers), race (minorities are more likely), and socioeconomic status (juveniles living in poor households are more likely, especially for serious forms of delinquent behaviors) (Hawkins, Catalano, \& Miller, 1992; Hawkins et al., 2000; Loeber \& Farrington, 2000; McLoyd, 1998; Nagin \& Tremblay, 2001). Because of the existence of multiple problems and risks, predicting juvenile delinquency outcomes is difficult (Ford, Chapman, Hawke, \& Albert, 2007; Green, Gesten, Greenwald, \& Salcedo, 2008; Gutman, Sameroff, \& Cole, 2003). Predicting detention placement and recidivism is particularly difficult.

\section{Recidivism}

Research that attempts to predict juvenile recidivism has been limited, with results generally accounting for approximately $20 \%$ of the variance (Katsiyannis, Zhang, Barrett, \& Flaska, 2004). Many of these models measured recidivism as re-adjudication by the juvenile court, and not recidivism into a detention center or incarceration facility (Ashford \& LeCroy, 1990; Katsiyannis \& Archwarmety, 1997). When measuring recidivism as re-adjudication, identified predictive factors of importance for this study include age at first offense (Ashford \& LeCroy, 1990; Brunner, 1993; Weaver \& Wootton, 1992), severity or seriousness of delinquency (Archwarmety \& Katsiyannia, 2000; Brunner, 1993; Frazier \& Cochran, 1986; Wierson \& Forehand, 1995), prior arrest (Ashford \& LeCroy, 1990; Lattimore, Fisher, \& Linster, 1995), lower academic achievement (Foley, 2001), behavioral problems including impulsivity (Hagan \& King, 1997), and race (Leiber \& Fox, 2005; Pope, Lovell, \& Hsia, 2002; Webb, 2006).

While measuring recidivism as a re-adjudication is informative, not all youth in this situation are subsequently placed into a detention center. This detention center placement is of particular interest in this study, because it often increases subsequent youth offending and recidivism (Justice Policy Institute, 2009; Soler, Shoenberg, \& Schindler, 2009). In other words, the experience of detention is unique and this experience makes it more likely that detained youth will continue 
to engage in delinquent behavior, and it may increase the odds of recidivism (Holman \& Ziedenberg, 2006). Hence, it is important to identify the risk factors that impact both detention placement as well as detention placement recidivism.

There are a limited number of studies that define recidivism as a return placement into a detention or incarceration facility. In a review of factors which predict recidivism to placement, carrying a weapon, gang membership, and neglect or abuse by a parent was found significant (Benda \& Tollett, 1999). Others found that youth who recidivated to placement were more likely to have both personal- and school-related problems (Wordes, Bynum, \& Corley, 1994), and the likelihood of being detained was greater for minority youth compared to nonminority youth even for the same offense (Feld, 1995). Most recently, in a review of what legal and extra-legal factors predicted detention, race (African-American and Hispanic), prior arrest, and personal crimes were found significant (Webb, 2006).

\section{Youth mental health problems, delinquency, and recidivism}

Mental health problems and disorders are linked to youth offending behaviors and delinquency adjudication; though it is not clear if this link is direct or if these difficulties lead to other risk factors, poor decision-making, or the interaction of various other risks (Grisso, 2008; Heilbrun, Goldstein, \& Redding, 2005; Moffitt \& Scott, 2008, chap. 35; Shufelt \& Cocozza, 2006). Still, reviews have consistently found that children and youth who are involved with mental health services have a significantly higher risk for juvenile court involvement (Rosenblatt, Rosenblatt, \& Biggs, 2000; Vander-Stoep, Evans, \& Taub, 1997).

A number of pathways have been established which link specific childhood mental health difficulties to juvenile court involvement. Developmental studies have found behavioral and emotional problems to be predictive of later delinquency and substance abuse (Dishion, Capaldi, \& Yoerger, 1999; O’Donnell, Hawkins, Catalano, Abbott, \& Day, 1995). Similarly, early childhood aggressive behaviors have been found predictive of later delinquent behaviors and activities (Tremblay \& LeMarquand, 2001). Attention and hyperactivity problems are linked to later highrisk taking and more violent offending behavior (Elander, Siminoff, Pickles, Holmshaw, \& Rutter, 2000; Hawkins et al., 1998). Antisocial behaviors and emotional problems in early childhood are markers for later delinquent activities (Wasserman et al., 2003). In addition, childhood depression and attention-deficit hyperactivity disorder (ADHD) have been found linked to later delinquency, evidenced through physical aggression and stealing behaviors (Goldstein, Olubadewo, Redding, \& Lexcen, 2005; Moffitt \& Scott, 2008, chap. 35; Ryan \& Redding, 2004).

Findings have been mixed regarding the relationship between mental health treatment needs (including substance abuse) and severity of juvenile court disposition. Indeed, youth mental health problems (broadly defined) have been found to predict both less and more severe dispositions; whereas substance abuse leads to more severe sanctions, including confinement (Campbell \& Schmidt, 2000; Fader, Harris, Jones, \& Poulin, 2001; Lyons, Baerger, Quigley, Erluch, \& Griffin, 2001; McReynolds, Schwalbe, \& Wasserman, 2010; Schwalbe, Hatcher, \& Maschi, 2009).

Youthful offenders needing secure placement pose a particularly difficult challenge to the juvenile courts, for juvenile detention and incarceration facilities are disproportionately populated by youth with at least one, if not multiple, mental health disorders and/or school-related disabilities (Garland et al., 2001; Mallett, 
2009; Teplin et al., 2006). Within these correctional facilities, $60 \%$ of the youth have an identified mental health disorder (with $20 \%$ of these disorders severely impacting functioning) (Grisso, 2008), over 35\% of the youth have an identified special education disability (Mears \& Aron, 2003), and between 30 and 50\% of the youth have a significant substance abuse disorder (Chassin, 2008).

\section{Suicidal behaviors}

This situation becomes more complicated when reviewing youth mental health problems along with prior suicide attempt. Suicide is a significant concern for detained and incarcerated youth, with 110 suicides occurring between 1995 and 1999 (Hayes, 2009), a rate that is multiple times more frequent than what occurs in the general youth community (Kaczmarek, Hagan, \& Kettler, 2006). In addition, in one study of suicides in Utah, $63 \%$ of youth in the community who completed the suicide had past juvenile justice system contact (Gray et al., 2002). While suicide completion is tragic, the reports of suicide ideation and attempts look to be significantly greater within this confined youthful offender population than in the general youth population. In one study of 900 incarcerated youth, over $30 \%$ reported a past suicide attempt (Putnins, 2005); while in a most recent nationally representative survey of over 7000 youthful offenders being held in facilities, over $22 \%$ reported a past suicide attempt (Sedlak \& McPherson, 2010).

A number of youth suicide risk factors are relevant here and include numerous mental health disorders, drug use, antisocial behaviors, and delinquency (Epstein \& Spirito, 2009; Flisher et al., 2000; Maris, Berman, \& Silverman, 2000; Thompson, Ho, \& Kingree, 2007). Aggression frequency and violent behaviors increased with increased suicidality levels (Vannatta, 1996); while getting involved with fights and using weapons were found to be high risks for suicide ideation (Evans, Marte, Betts, \& Silliman, 2001). These acting out and antisocial behaviors, and specifically conduct disorder, were often found among suicidal youth (Brent et al., 1993). Evidence of the ADHD link to suicide attempts is less clear, with some researchers finding higher rates of ADHD in these populations (Ruchkin, Schwab-Stone, Koposov, Vermeiren, \& King, 2003; Swensen, Kruesi, Allen, Beusching, \& Secnik, 2002), and others not finding such a connection (Renaud, Brent, Birmaher, Chiappetta \& Bridge, 1999).

However, predicting suicide risk is not easy because risk factors vary in their impact and intensity for incarcerated and formally adjudicated youth, though this population is in general at a higher suicidal-behavior risk (Epstein \& Spirito, 2009; Evans, Hawton, \& Rodham, 2004). Even when other risk factors - age, ethnicity, gender, alcohol and drug problems, depression, and impulsivity - were accounted for, delinquency was still related to suicidal ideation and attempts up to one year after adjudication and to ideation up to seven years after adjudication (Thompson et al., 2007).

\section{Justification for the study}

As discussed, only a small number of studies have focused on offenders who recidivate to placement; therefore, additional research is needed. Continuing these inquiries and identifying what legal and extra-legal factors predict recidivism to detention placement is important in understanding and directing preventative 
programs. If certain youth risks, behaviors, and/or disabilities are clearly identified, then early intervention efforts may decrease or help youth desist delinquent offending and subsequent detention or incarceration. Decreasing youth recidivism (offending and incarceration) is effective public policy, saving limited fiscal resources, and improving public safety (Caldwell, Vitacco, \& Van Rybroek, 2006; Gatti, Tremblay, \& Vitaro, 2009; Loughran et al., 2009; Soler et al., 2009).

\section{Research question}

What demographic, educational, mental health, substance dependence, and courtrelated variables predict secure detention placement recidivism in a population of court involved youth?

\section{Methods}

\section{Sampling}

The sampling frame for this study consisted of court involved youth from two counties over a distinct period of time. An a priori analysis was conducted to calculate an appropriate sample size. Given the annual population size of 2300 delinquent probation-supervised youth from the first county (urban) and an annual population size of 300 delinquent probation-supervised youth from the second county (rural), it was determined that a sample size of 343 (over three years, from 2006 to 2008) from the first county and a sample size of 90 (over one year - 2008) from the second county would provide the appropriate five percent margin of error and $95 \%$ confidence interval, assuming a population proportion of 50\% (Royse, Thyer, Padgett, \& Logan, 2006). A simple random sample was drawn for each population year of the counties' juvenile delinquent probation-supervised population; youth who had been adjudicated delinquent during that calendar year and chosen for the study did not include youth transferred to criminal (adult) court (though this number of transferred youth represented less than half of one percent of the total). A total of 433 (not duplicated) youth were included in this study sample: urban county $2006=100 ; 2007=137 ; 2008=105$; rural county $2008=91$.

\section{Data collection}

Data were collected from existing de-identified files provided by each county's juvenile court. Each file contained official records associated with each youth in the study sample. Specifically, juvenile court histories, probation supervision case files, school records, and mental health assessments were provided. Data from the case records were coded and entered into a statistical software package. Each case entered was evaluated for proper coding and correct data entry. Inter-coder reliability was high (.96).

\section{Measurement}

\section{Independent variables}

Theoretically important demographic, educational, mental health, and juvenile court-related variables were measured. Demographic variables include age (in years), gender $($ male $=1)$, race $($ Caucasian $=1$, all other $=0)$, and county of residence 
when first adjudicated delinquent (rural $=1$, urban $=0$ ). Three separate education disability variables were measured - severely behaviorally handicapped (SBH), developmentally handicap (DH), and severely emotionally disturbed (SED). For each variable, diagnosis was made prior to first delinquency adjudication, by a licensed provider using DSM-IV criteria (yes $=1$ indicates an existing diagnosis). Mental health-related variables that were measured include ADHD, conduct disorder, oppositional defiant disorder, bipolar disorder, depression, adjustment disorder, post-traumatic stress disorder (PTSD), and anxiety disorder. Additionally, alcohol dependence and substance use disorders were also measured. Individuals were counted as alcohol dependent if they had ever been diagnosed with alcohol dependence, and individuals were counted as substance dependent if they had ever been diagnosed by a licensed provider using DSM-IV criteria with dependence to any drugs other than alcohol. All diagnoses were made prior to the youth's first delinquency adjudication by licensed providers using DSM-IV criteria (yes $=1$ indicates a prior diagnosis). In addition, youth's self-report of a prior suicide attempt was also measured (yes $=1$ indicates a prior suicide attempt). Juvenile court-related variables included the total number of times each youth was adjudicated delinquent (in number of times), the youth's age at first delinquency (in years), the youth's total number of court offenses which includes multiple offenses over time (in number of court offenses), if the youth had ever been convicted of a felony (yes =1), if youth had ever been convicted of a misdemeanor (yes $=1$ ), and if the youth had ever been convicted of a property crime, personal crime, drug crime, status offense, or violation of court order (VCO) (all coded 1 for yes).

\section{Dependent variable}

One dependent variable, recidivism, was measured. Youth were coded (yes=1) if they were sentenced to detention, were released from custody, and then subsequently placed back into detention.

A small number of missing variables were imputed with either the mean (for continuous variables) or the mode (for categorical variables), except for juvenile court-related variables where missing cases (only one to two per variable) were eliminated from the analysis. There were no missing cases for the dependent variable (see Table 1).

\section{Data analysis}

A bivariate correlation analysis among all variables was first conducted. Second, bivariate logistic regression was used to assess the bivariate relationship between each of the independent and control variables and the dependent variable, recidivism to secure detention placement. Variable pairs that were significant at a p-value greater than .1 in the bivariate mode were then entered into a forward stepwise multivariable model (see Table 2).

Additionally, a second multivariable forward stepwise logistic model with all the potential independent variables was developed. This was done so that two theoretically relevant variables which have demonstrated impact on detention placement would be included in the multivariate model. The models differed only in the inclusion of ADHD and race, which were not significant in bivariate relationships. The final model included age, race, ADHD, conduct disorder, suicide attempt, number 
Table 1. Descriptive statistics of variables.

\begin{tabular}{|c|c|c|c|}
\hline & Variable & Yes $($ coded 1$)$ & No $($ coded 0$)$ \\
\hline Predictor & Recidivitated to placement & $71(16.4 \%)$ & $362(83.6 \%)$ \\
\hline \multirow[t]{4}{*}{ Control } & Age & $\begin{array}{l}\text { Mean }=15.2 \\
(\mathrm{SD}=1.6)\end{array}$ & \\
\hline & Gender & Male $303(70.0 \%)$ & Female $130(30.0 \%)$ \\
\hline & Race & $\begin{array}{l}\text { Caucasian } 155 \\
(35.8 \%)\end{array}$ & $\begin{array}{l}\text { All other } 278 \\
(64.2 \%)\end{array}$ \\
\hline & Country & Urban $343(79.2 \%)$ & Rural 90 (20.8\%) \\
\hline \multirow[t]{3}{*}{ Education } & $\mathrm{SBH}$ & $29(6.7 \%)$ & $404(93.3 \%)$ \\
\hline & $\mathrm{DH}$ & $5(1.2 \%)$ & $428(98.8 \%)$ \\
\hline & SED & $30(6.9 \%)$ & $403(93.1 \%)$ \\
\hline \multirow{11}{*}{$\begin{array}{l}\text { Mental } \\
\text { health }\end{array}$} & ADHD & $103(23.8 \%)$ & $330(76.2 \%)$ \\
\hline & Conduct disorder & $40(9.2 \%)$ & $393(90.8 \%)$ \\
\hline & $\begin{array}{l}\text { Oppositional defiant } \\
\text { Disorder }\end{array}$ & $33(7.9 \%)$ & $400(92.4 \%)$ \\
\hline & Bipolar disorder & $34(7.9 \%)$ & $399(92.1 \%)$ \\
\hline & Depression & $52(12.0 \%)$ & $381(88.0 \%)$ \\
\hline & Adjustment disorder & $10(2.3 \%)$ & $423(97.7 \%)$ \\
\hline & PTSD & $10(2.3 \%)$ & $423(97.7 \%)$ \\
\hline & Anxiety disorder & $11(2.5 \%)$ & $422(97.5 \%)$ \\
\hline & Alcohol dependence & $17(3.9 \%)$ & $416(96.1 \%)$ \\
\hline & Substance use disorders & $64(14.8 \%)$ & $369(85.2 \%)$ \\
\hline & Suicide attempt & $53(12.2 \%)$ & $380(87.8 \%)$ \\
\hline \multirow[t]{9}{*}{$\begin{array}{l}\text { Juvenile } \\
\text { court }\end{array}$} & $\begin{array}{l}\text { Times adjudicated } \\
\text { Delinquent }\end{array}$ & Mean $=1.3(\mathrm{SD}=0.6)$ & \\
\hline & Age at first delinquency & $\begin{array}{l}\text { Mean }=14.6 \\
(\mathrm{SD}=1.6)\end{array}$ & \\
\hline & Number of Court Offenses & Mean $=4.4(\mathrm{SD}=3.8)$ & \\
\hline & Felony $^{\mathrm{a}}$ & $237(54.9 \%)$ & $195(45.1 \%)$ \\
\hline & Misdemeanor & $358(82.7 \%)$ & $75(17.3 \%)$ \\
\hline & Property crime & $238(55.0 \%)$ & $195(45.0 \%)$ \\
\hline & Personal crime ${ }^{\mathrm{a}}$ & $261(60.4 \%)$ & $171(39.6 \%)$ \\
\hline & Drug crime ${ }^{b}$ & $85(64.9 \%)$ & $346(80.3 \%)$ \\
\hline & $\mathrm{VCO}^{\mathrm{a}}$ & $149(34.5 \%)$ & $283(65.5 \%)$ \\
\hline
\end{tabular}

Note: Frequencies and percentages in parenthesis $(n=433)$.

a 1 missing cases.

$\mathrm{b}_{2}$ missing cases.

of court offenses, and previous conviction on a misdemeanor offense. This model was tested for stability using repeated $80 \%$ validation samples from the data. In each case, the same variables were identified and the estimates were within the confidence intervals of the final model. The overall model was significant at predicting detention placement recidivism $X^{2}=140.63[\mathrm{df}=7] p<.001$ and correctly classified $88.5 \%$ of cases; Nagelkerke $R^{2} .47$.

\section{Findings}

In all, seven variables significantly predict juvenile offenders' secure detention placement recidivism. Predictors that made this recidivism more likely include a previous diagnosis of conduct disorder (10 times more likely), a self-reported previous suicide attempt (almost three times more likely), age (for each additional year, 1.3 times more likely), and number of court offenses (for each additional offense, 
Table 2. Univariate logistic regression with recidivism $(n=433)$.

\begin{tabular}{|c|c|c|c|}
\hline & Variable & Univariate odds ratio & $p$-value \\
\hline \multirow[t]{4}{*}{ Control } & $\mathrm{Age}^{\mathrm{a}}$ & 1.271 & .007 \\
\hline & Male & 1.442 & .223 \\
\hline & Caucasian & .694 & .053 \\
\hline & Urban & 3.273 & .008 \\
\hline \multirow[t]{3}{*}{ Education } & SBH & 6.658 & $<.001$ \\
\hline & $\mathrm{DH}$ & 1.000 & .493 \\
\hline & SED & .346 & .153 \\
\hline \multirow[t]{11}{*}{ Mental health } & ADHD & .920 & .786 \\
\hline & Conduct disorder & 6.706 & $<.001$ \\
\hline & Oppositional defiant disorder & 1.413 & .439 \\
\hline & Bipolar disorder & 0.870 & .782 \\
\hline & Depression & 2.094 & .032 \\
\hline & Adjustment disorder & 2.237 & .252 \\
\hline & PTSD & .560 & .586 \\
\hline & Anxiety disorder & 1.952 & .332 \\
\hline & Alcohol dependence & 1.097 & .887 \\
\hline & Substance use disorders & 3.752 & $<.001$ \\
\hline & Suicide attempt & 2.851 & .001 \\
\hline \multirow[t]{9}{*}{ Juvenile court } & Times adjudicated delinquent $\mathrm{a}^{\mathrm{a}}$ & 2.012 & .001 \\
\hline & Age at first delinquency ${ }^{\mathrm{a}}$ & .781 & .002 \\
\hline & Number of court offenses ${ }^{a}$ & 1.390 & $<.001$ \\
\hline & Felony $^{\mathrm{c}}$ & 5.055 & $<.001$ \\
\hline & Misdemeanor & 1.036 & .919 \\
\hline & Property crime & 2.204 & .005 \\
\hline & Personal crime ${ }^{b}$ & 1.052 & .850 \\
\hline & Drug crime ${ }^{c}$ & 2.717 & $<.001$ \\
\hline & $\mathrm{VCO}$ & 1.596 & .077 \\
\hline
\end{tabular}

${ }^{\mathrm{a} O d d s}$ ratio is per unit increase.

${ }^{\mathrm{b}} 1$ missing case.

${ }^{\mathrm{c}} 2$ missing cases.

Table 3. Multivariable logistic regression predicting recidivism.

\begin{tabular}{lccrr}
\hline Independent variables & $\mathrm{B}$ & S.E. & Wald & Odds Ratio \\
\hline Numbers of court offenses & $.379^{* * *}$ & .052 & 54.118 & 1.461 \\
Age & $.237^{*}$ & .122 & 3.769 & 1.267 \\
Caucasian & $-.818^{*}$ & .394 & 4.300 & .441 \\
ADHD & $-.862^{*}$ & .446 & 3.739 & .422 \\
Conduct disorder & $2.365^{* * *}$ & .470 & 25.357 & 10.646 \\
Suicide attempt & $1.096^{*}$ & .448 & 5.999 & 2.993 \\
Misdemeanor & $-1.232^{* *}$ & .451 & 7.453 & .292 \\
Constant & $-6.429^{* *}$ & 1.956 & 10.807 & .002 \\
\hline
\end{tabular}

${ }^{*} p<.05 ;{ }^{* *} p<.01 ;{ }^{* * *} p<.001$.

1.5 times more likely). Conversely, predictors that made this recidivism less likely to occur include race (Caucasians were more than twice as less likely), a previous diagnosis of ADHD (more than twice less likely), and a conviction for a misdemeanor (3.4 times as less likely) (see Table 3). 


\section{Discussion}

These study findings are of interest because of the paucity of studies on predicting juvenile offender recidivism to detention, and because of the confirmatory (expected) and unexpected predictors. There is nothing unexpected for juvenile offenders who are older or have increasing number of court offenses being at a higher risk for recidivism (Ashford \& LeCroy, 1990; Brunner, 1993; Weaver \& Wootton, 1992; Webb, 2006). Likewise, convictions for misdemeanors are not expected to be highly predictive of secure detention placement, or here for placement recidivism (Archwarmety \& Katsiyannia, 2000; Brunner, 1993; Frazier \& Cochran, 1986; Wierson \& Forehand, 1995). Caucasian youth were also expected to be less likely to be placed into secure detention, and in this case, recidivate to placement. This disproportionate minority confinement problem is well documented across many jurisdictions (Feld, 1995; Leiber \& Fox, 2005; Pope et al., 2002; Webb, 2006), and was also found here.

Less clear though is the impact different mental health problems or disorders have on delinquency and subsequent detention. Conduct disorder was the strongest predictor of recidivism into detention placement, which has been found to varying degrees by others (Hagan \& King, 1997; McReynolds et al., 2010). However, other researchers have often failed to differentiate by disorder and many times had grouped their mental health problems into one measured variable (Campbell \& Schmidt, 2000; Fader et al., 2001; Lyons et al., 2001). This study's data collection allowed the identification and differentiation of individual mental health diagnoses. With the second disorder, ADHD was found to make recidivism less likely for the juvenile offender. This has been measured before as impulsivity, though not in detention prediction (Hagan \& King, 1997). While both conduct disorder and ADHD have externalizing features, in other words, acting out behaviors, impulsive reactions, and over-reaction symptoms, they may be handled differently by juvenile court personnel. It may be that the more severe aggression symptoms associated with conduct disorder leads to additional difficulties or court charges for the youth; while ADHD and its more impulsive or reactive symptoms do not lead to similar results.

The finding that a youth's past attempted suicide made recidivism more likely is unique. The interplay among youth suicidality, mental health disorders (particularly aggressive symptoms), drug use, and delinquency is complex (Epstein \& Spirito, 2009; Maris et al., 2000; Thompson et al., 2007). This finding has implications for these at-risk and detained juvenile offenders. If ongoing research (including community-based populations) confirms this suicide risk, then numerous youth-serving systems have an opportunity to intervene. The suicide attempts were reported to have occurred while the youth was in the community, prior to detention placement. These at-risk youth may have been in contact with the mental health system, and undoubtedly most were enrolled in a school system, presenting possible intervention and coordination points. In addition, standardized suicide risk assessments by experienced practitioners could be utilized within the detention centers; or better yet, at earlier juvenile justice system processing points to identify those at risk for suicide. This may be very important because detention and incarceration are also risk factors for suicide, making the placement experience itself potentially harmful for youth (Centers for Disease Control \& Prevention, 2009). 
Indeed, what is known is that youth suicide and attempts continue to be an alarming problem: seven percent of the general youth population has attempted suicide in the past year (Centers for Disease Control \& Prevention, 2009). Additionally, up to $80 \%$ of youth with a serious mental health disorder do not receive needed services (Kataoka, Zhang, \& Wells, 2002). Even following a suicide attempt, only $40 \%$ of youth needing mental health services receive help (Centers for Disease Control \& Prevention, 2009). This problem has been identified by policy-makers as exemplified by the Garrett Lee Smith Memorial Act of 2004, which mandates suicide screening and interventions for youth. The National Registry of Evidenced-Based Programs and Practices identified Columbia University's TeenScreen Program: Mental Health Check-ups for Youth (2003) as an ideal model. This program focuses on screenings for mental health, suicidal ideation, and substance use disorders in community settings such as schools and clinics (Horowitz, 2009). Youth who screen positive are then referred to a variety of community agencies for further assessment and or treatment. Community-based screenings for mental health disorders, substance use, and suicide risk can be completed easily and effectively using the Diagnostic Predictive Scales-8. Although their use has expanded in recent years, evidenced-based screening and intervention programs are currently underutilized in community-based settings (Payne, 2009). Given the findings from this current research, the benefits of this type of screening and subsequent referrals could be even more effective, perhaps impacting juvenile delinquency and detention placement.

\section{Limitations}

This study has some important limitations worth noting. First, data were gathered from existing case records. Hence, any errors within the case files are unknown. Second, there may be some underdiagnosis or under-reporting of some of the independent variables. For example, some youth could have struggled with the ADHD symptoms prior to their first arrest, but may have never been properly diagnosed. Similarly, the suicide measurement relies on self-report by the youth. There is a possibility that this variable was under-reported. Finally, although a random sampling method was used, the findings are not widely generalizeable due to the narrow sampling frame.

\section{Conclusions}

A number of juvenile offenders experience multiple placements into secure detention. This detention is an oftentimes ineffective method for improving outcomes for delinquent youth. This study evaluated a two county population of delinquent youth to investigate the legal and extra-legal variables that predict recidivism. This study found that youth with a previous diagnosis of conduct disorder, a selfreported previous suicide attempt, those who were older, and those who had an increased number of court offenses are more likely to recidivate. If the goal is to reduce recidivism that leads to subsequent detention placement, it is imperative for all stakeholders to understand these factors that may serve as early detection points for concern and intervention. Utilizing a community-based suicide and mental health screening and referral approach may help to identify and assist these highrisk youth in receiving needed services prior to delinquency and formal juvenile court involvement. 


\section{References}

Archwamety, T., \& Katsiyannia, A. (2000). Academic remediation, parole violations, and recidivism rates among delinquent youths. Remedial and Special Education, 21, 161170.

Ashford, J.B., \& LeCroy, C.W. (1990). Juvenile recidivism: A comparison of three prediction instruments. Adolescence, 25, 441-450.

Benda, B.B., \& Tollet, C.L. (1999). A study of recidivism of serious and persistent offenders among adolescents. Journal of Criminal Justice, 27(2), 111-126.

Bor, W., McGee, T.R., \& Fagan, A.A. (2004). Early risk factors for adolescent antisocial behaviour: An Australian longitudinal study. Australian \& New Zealand Journal of Psychiatry, 38, 365-372.

Brent, D.A., Perper, J.A., Moritz, G., Allman, C., Friend, A., Roth, C., ... Baugher, M. (1993). Psychiatric risk factors for adolescent suicide: A case-control study. Journal of the American Academy of Child \& Adolescent Psychiatry, 32(3), 521-529.

Brunner, M. (1993). Reduced recidivism and increased employment opportunity through research-based reading instruction. Washington, DC: Office of Juvenile Justice and Delinquency Prevention, US Department of Justice.

Bursik, R., \& Grasmick, G.H. (1993). Neighborhoods and crime. New York, NY: Lexington.

Bursik, R., \& Grasmick, G.H. (1995). Neighborhood-based networks and the control of crime and delinquency. In Hugh Barlow (Ed.), Crime and public policy (pp. 107-130). Boulder, CO: Westview.

Caldwell, M.F., Vitacco, M., \& Van Rybroek, G.J. (2006). Are violent delinquents worth treating?: A cost-benefit analysis. Journal of Research in Crime and Delinquency, 43(2), $148-168$

Campbell, M.A., \& Schmidt, F. (2000). Comparison of mental health and legal factors in the disposition outcome of young offenders. Criminal Justice and Behavior, 27, 688-715.

Centers for Disease Control and Prevention. (2009). Suicide prevention: Youth suicide. Atlanta, GA: National Center for Injury Prevention and Control Division of Violence Prevention.

Chassin, L. (2008). Juvenile justice and substance abuse. The Future of Children, 18(2), $165-184$.

Davis, A., Tsukida, C., Marchionna, S., \& Krisberg, B. (2008). The declining number of youth in custody in the juvenile justice system. Oakland, CA: National Council on Crime and Delinquency.

Dishion, T.J., Capaldi, D.M., \& Yoerger, K. (1999). Middle childhood antecedents to progression in male adolescent substance use: An ecological analysis of risk and protection. Journal of Adolescent Research, 14, 175-205.

Elander, J., Siminoff, E., Pickles, A., Holmshaw, J., \& Rutter, M. (2000). A longitudinal study of adolescent and adult conviction rates among children referred to child psychiatric services for behavioural or emotional problems. Criminal Behaviour and Mental Health, 10, 40-59. 
Epstein, J.A., \& Spirito, A. (2009). Risk factors for suicidality among a nationally representative sample of high school students. Suicide and Life-Threatening Behavior, 39(3), 241-251.

Evans, E., Hawton, K., \& Rodham, K. (2004). Factors associated with suicidal phenomena in adolescents: A systematic review of population-based studies. Clinical Psychology Review, 24, 957-979.

Evans, W.P., Marte, R.M., Betts, S., \& Silliman, B. (2001). Adolescent suicide risk and peer related violent behaviors and victimization. Journal of Interpersonal Violence, 16, 13301348.

Fader, J.J., Harris, P.W., Jones, P.R., \& Poulin, M.E. (2001). Factors involved in decision on commitment to delinquency programs for first-time juvenile offenders. Justice Quarterly, $18,323-341$.

Feld, B.C. (1995). The social context of juvenile justice administration: Racial disparities in urban juvenile courts. In K.K. Leonard, C.E. Pope, \& W.H. Feyerherm (Eds.), Minorities in juvenile justice (pp. 166-226). Thousand Oaks, CA: Sage.

Flisher, A.J., Kramer, R.A., Hoven, C.W., King, R.A., Bird, H.R., \& Davies, M. (2000). Risk behavior in a community sample of children and adolescents. Journal of the American Academy of Child and Adolescent Psychiatry, 39, 881887.

Foley, R. (2001). Academic characteristics of incarcerated youth and correctional education programs: A literature review. Journal of Emotional and Behavioral Disorders, 9, 248259.

Ford, J.D., Chapman, J.F., Hawke, J., \& Albert, D. (2007). Trauma among youth in the juvenile justice system: Critical issues and new directions. Delmar, NY: National Center for Mental Health and Juvenile Justice.

Frazier, C., \& Cochran, J. (1986). Detention of juveniles: Its effects on subsequent juvenile court proceedings. The Journal of Criminal Law and Criminology, 76, 1132-1152.

Garland, A., Hough, R.L., McCabe, K.M., Yeh, M., Wood, P.A., \& Aarons, G.A. (2001). Prevalence of psychiatric disorders in youths across five sectors of care. Journal of the American Academy of Child and Adolescent Psychiatry, 40(4), 409-418.

Gatti, U., Tremblay, R.E., \& Vitaro, F. (2009). Iatrogenic effect of juvenile justice. Journal of Child Psychology and Psychiatry, 50(8), 991-998.

Goldstein, N., Olubadewo, O., Redding, R., \& Lexcen, F. (2005). Mental health disorders: The neglected risk factor in juvenile delinquency. In K. Heilbrum (Ed.), Juvenile delinquency: Prevention, assessment and intervention (pp. 85-110). New York, NY: Oxford University Press.

Gray, D., Achilles, J., Keller, T., Tate, D., Haggard, L., Rolfs, R., Cazier, C., Workman, J., \& McMahon, W.M. (2002). Utah youth suicide study, phase I: Government agency contact before death. Journal of the American Academy of Child \& Adolescent Psychiatry, 41(4), 427-434.

Green, A.E., Gesten, E.L., Greenwald, M.A., \& Salcedo, O. (2008). Predicting delinquency in adolescence and young adulthood. Youth Violence and Juvenile Justice, 6(4), 323342 .

Grisso, T. (2008). Adolescent offenders with mental disorders. The Future of Children, 18 (2), 143-164.

Gutman, L.M., Sameroff, A.J., \& Cole, R. (2003). Academic growth curve trajectories from 1st grade to 12th grade: Effects of multiple social risk factors and preschool child factors. Developmental Psychology, 39, 777-790.

Hagan, M.P., \& King, S.L. (1997). Accuracy of psychologists' short-term predictions of future criminal behavior among juveniles. Journal of Offender Rehabilitation, 25, 129141.

Hawkins, J.D., Catalano, R.F., \& Miller, J.Y. (1992). Risk and protective factors for alcohol and other drug problems in adolescence and early adulthood: Implications for substance abuse prevention. Psychological Bulletin, 112, 64-105.

Hawkins, J.D., Herrenkohl, T.L., Farrington, D.P., Brewer, D., Catalano, R.F., \& Harachi, T. W. (1998). A review of predictors of youth violence. In R. Loeber \& D.P. Farrington (Eds.), Serious and violent juvenile offenders: Risk factors and successful interventions (pp. 106-146). Thousand Oaks, CA: Sage. 
Hawkins, D.J., Herrenkohl, T.I., Farrington, D.P., Brewer, D., Catalano, R.F., Harachi, T.W., \& Cothern, L. (2000). Predictors of youth violence. Washington, DC: Office of Juvenile Justice and Delinquency Prevention, Office of Justice Programs, US Department of Justice.

Hay, C., Fortson, E., Hollist, D., Altheimer, I., \& Schaible, L. (2006). The impact of community disadvantage on the relationship between the family and juvenile crime. Journal of Research in Crime and Delinquency, 43(4), 326-356.

Hayes, L.M. (2009). Characteristics of juvenile suicide in confinement. Washington, DC: Juvenile Justice Bulletin, Office of Juvenile Justice and Delinquency Prevention, Office of Justice Program, US Department of Justice.

Heilbrun, K., Goldstein, N., \& Redding, R. (2005). Juvenile delinquency: Prevention, assessment, and intervention. New York, NY: Oxford University Press.

Holman, B., \& Ziedenberg, J. (2006). The dangers of detention: The impact of incarcerating youth in detention and other secure congregate facilities. Baltimore, MD: Annie E. Casey Foundation.

Horowitz, L.M. (2009). Suicide screening in schools, primary care and emergency departments. Current Opinion in Pediatrics, 21(5), 620-627.

Justice Policy Institute. (2009). The costs of confinement: Why good juvenile justice policies make good fiscal sene. Washington, DC: Justice Policy Institute.

Kaczmarek, T.L., Hagan, M.P., \& Kettler, R.J. (2006). Screening for suicide among juvenile delinquents. International Journal of Offender Therapy and Comparative Criminology, 50(2), 204-217.

Kataoka, S.H., Zhang, L., \& Wells, K.B. (2002). Unmet need for mental health care among US children: Variation by ethnicity and insurance status. American Journal of Psychiatry, 159(9), 1548-1555.

Katsiyannis, A., \& Archwamety, T. (1997). Factors related to recidivism among delinquent youths in a state correctional facility. Journal of Child and Family Studies, 6(1), 43-55.

Katsiyannis, A., Zhang, D., Barrett, D.E., \& Flaska, T. (2004). Background and psychosocial variables associated with recidivism among adolescent males: A 3-year investigation. Journal of Emotional and Behavioral Disorders, 12(1), 23-29.

Knoll, C., \& Sickmund, M. (2010). Delinquency cases in juvenile court, 2007. Washington, DC: Office of Juvenile Justice and Delinquency Prevention, Office of Justice Programs, US Department of Justice.

Lattimore, P.K., Fisher, C.A., \& Linster, R.L. (1995). Predicting rearrest for violence among serious youthful offenders. Journal of Research in Crime and Delinquency, 32, 54-83.

Leiber, M.J., \& Fox, K. (2005). Race and impact of detention on juvenile justice decision making. Crime \& Delinquency, 51(4), 470-497.

Loeber, R., \& Farrington, D.P. (2000). Young children who commit crime: Epidemiology, developmental origins, risk factors, early interventions, and policy implications. Developmental and Psychopathology, 12, 737-762.

Loughran, T., Mulvey, E., Schubert, C., Fagan, J., Pizuero, A., \& Losoya, S. (2009). Estimating a dose-response relationship between length of stay and future recidivism in serious juvenile offenders. Criminology, 47(3), 699-740.

Lynam, D., Moffitt, T., \& Stouthamer-Loeber, M. (1993). Explaining the relation between IQ and delinquency: Class, race, test motivation, school failure, or self-control? Journal of Abnormal Psychology, 102, 187-196.

Lyons, J., Baerger, D., Quigley, P., Erluch, J., \& Griffin, E. (2001). Mental health service needs of juvenile offenders: A comparison of detention, incarceration, and treatment settings. Children's Services: Social Policy, Research, and Practice, 4, 69-85.

Mallett, C. (2009). Disparate juvenile court outcomes for disabled delinquent youth: A social work call to action. Child \& Adolescent Social Work Journal, 26(3), 197-208.

Mallett, C. (2011). Seven things juvenile courts should know about learning disabilities. Reno, NV: National Council of Juvenile and Family Court Judges.

Maris, R.W., Berman, A.L., \& Silverman, M.M. (2000). Comprehensive textbook of suicidiology. New York, NY: Guilford Press.

McLloyd, V.C. (1998). Socioeconomic disadvantage and child development. American Psychologist, 53, 185-204. 
McReynolds, L.S., Schwalbe, C.S., \& Wasserman, G.A. (2010). The contribution of psychiatric disorder to juvenile recidivism. Criminal Justice and Behavior, 37(2), 204-216.

Mears, D., \& Aron, L. (2003). Addressing the needs of youth with disabilities in the juvenile justice system: The current state of knowledge. Washington, DC: The Urban Institute.

Moffitt, T., \& Scott, S. (2008). Conduct disorders of childhood \& adolescence. In M. Rutter (Ed.), Child psychiatry. London: Wiley-Blackwell.

Nagin, D.S., \& Tremblay, R.E. (2001). Parental and early childhood predictors of persistent physical aggression in boys from kindergarten to high school. Archives of General Psychiatry, 58, 389-394.

O’Donnell, J., Hawkins, J.D., Catalano, R.F., Abbott, R.D., \& Day, L.E. (1995). Preventing school failure, drug use, and delinquency among low-income children: Long-term interventions in elementary school. American Journal of Orthopsychiatry, 65, $87-100$.

Payne, C.M. (2009). Assessing the utility of the diagnostic predictive scales- 8 within a school-based mental health screening design (Dissertations Abstracts International, A70 (6-A), 1924). Proquest Information and Learning US.

Pope, C.E., Lovell, R., \& Hsia, H.M. (2002). Synthesis of disproportionate minority confinement (DMC) research literature (1989-1999). Washington, DC: Office of Juvenile Justice and Delinquency Prevention, US Department of Justice.

Putnins, A.L. (2005). Correlates and predictors of self-reported suicide attempts among incarcerated youths. International Journal of Offender Therapy and Comparative Criminology, 49, 143-157.

Puzzanchera, C. (2009). Juvenile arrests 2008. Washington, DC: Juvenile Justice Bulletin, Office of Juvenile Justice and Delinquency Prevention, Office of Justice Programs, US Department of Justice.

Renaud, J., Brent, D.A., Birmaher, B., Chiappetta, L., \& Bridge, J. (1999). Adolescent suicide in disruptive disorders. Journal of the American Academy of Child and Adolescent Psychiatry, 38, 846-851.

Rosenblatt, J.A., Rosenblatt, A.R., \& Biggs, E.E. (2000). Criminal behavior and emotional disorder: Comparing youth served by the mental health and juvenile justice systems. The Journal of Behavioral Health Services \& Research, 27(2), 227-237.

Royse, D., Thyer, B., Padgett, D., \& Logan, T. (2006). Program evaluation: An introduction. Belmont, CA: Thompson Brooks/Cole.

Ruchkin, V., Schwab-Stone, M., Koposov, R.A., Vermeiren, R., \& King, R.A. (2003). Suicidal ideations and attempts in juvenile delinquents. The Journal of Child Psychology and Psychiatry, 44(7), 1058-1066.

Ryan, E.P., \& Redding, R.E. (2004). Mood disorders in juvenile offenders. Psychiatric Services, 55, 1397-1407.

Sampson, R.J., Raudenbush, S.W., \& Earls, F. (1997). Neighborhoods and violent crime: A multilevel study of collective efficacy. Science, 277, 918-924.

Schwalbe, C.S., Smith-Hatcher, S., \& Maschi, T. (2009). The effects of treatment needs and prior social services use on juvenile court decision making. Social Work Research, 33(1), $31-40$.

Sedlak, A.J., \& McPherson, K. (2010). Survey of youth in residential placement: Youth's needs and services. Washington, DC: Westat Corporation.

Shufelt, J.L., \& Cocozza, J.J. (2006). Youth with mental health disorders in the juvenile justice system: Results from a multi-state prevalence study. Delmar, NY: National Center for Mental Health and Juvenile Justice.

Sickmund, M. (2008). Census of juveniles in residential placement databook. Washington, DC: Office of Juvenile Justice and Delinquency Prevention, Office of Justice Programs, US Department of Justice.

Sickmund, M. (2009). Juveniles in residential placement, 1997-2008. Washington, DC: Office of Juvenile Justice and Delinquency Prevention, Office of Justice Programs, US Department of Justice.

Soler, M., Shoenberg, D., \& Schindler, M. (2009). Juvenile justice: Lessons for a new era. Georgetown Journal on Poverty Law \& Policy, volume number XVI (Symposium Issue). 
Swensen, A.R., Kruesi, M.J.P., Allen, A.J., Beusching, D., \& Secnik, K. (2002). Self-injury and suicide in patients with attention-deficit/hyperactivity disorder. Poster session presented at the 49th annual meeting of the American Association of Child and Adolescent Psychiatry, San Francisco, CA.

Teplin, L., Abram, K., McClelland, G., Mericle, A., Dulcan, M., \& Washburn, D. (2006). Psychiatric disorders of youth in detention. Washington, DC: Office of Juvenile Justice and Delinquency Prevention, Juvenile Justice Bulletin, US Department of Justice.

Thompson, M.P., Ho, D., \& Kingree, J.B. (2007). Prospective association between delinquency and suicidal behaviors in a nationally representative sample. Journal of Adolescent Health, 40, 232-237.

Tremblay, R.E., \& LeMarquand, D. (2001). Individual risk and protective factors. In R. Loeber \& D.P. Farrington (Eds.), Child delinquents: Development, intervention, and service needs (137-164) (pp. 137-164). Thousand Oaks, CA: Sage Publications.

Tremblay, R.E., Nagin, D.S., Sequin, J.R., Zoccolillo, M., Zelazo, P.D., Boivin, M., ... Japel, C. (2004). Physical aggression during early childhood: Trajectories and predictors. Pediatrics, 114, e43-e50.

US Department of Justice. (2010). Performance measures. Washington, DC: Office of Juvenile Justice and Delinquency Prevention, Office of Justice Programs, US Department of Justice.

Vander-Stoep, A., Evans, C., \& Taub, J. (1997). Risk of juvenile justice system referral among children in a public mental health system. Journal of Mental Health Administration, 24, 428-421.

Vannatta, R. (1996). Risk factors related to suicidal behavior among male and female adolescents. Journal of Youth and Adolescence, 25, 149-160.

Wasserman, G.A., Keenan, K., Tremblay, R.E., Cole, J.D., Herrenkohl, T.I., Loeber, R., \& Petechuk, D. (2003). Risk and protective factors of child delinquency. Washington, DC: Office of Juvenile Justice and Delinquency Prevention, US Department of Justice.

Weaver, G.M., \& Wootton, R.R. (1992). The use of the MMPI special scales in the assessment of delinquent personality. Adolescence, 27, 545-554.

Webb, P. (2006). Predicting pre-adjudicatory detention decisions: An investigation of legal and extralegal factors. Journal of Ethnicity in Criminal Justice, 4(4), 37-50.

Wierson, M., \& Forehand, R. (1995). Predicting recidivism in juvenile delinquents: The role of mental health diagnoses and the qualification of conclusions by race. Behaviour Research and Therapy, 33, 63-77.

Wordes, M., Bynum, T., \& Corley, C. (1994). Locking up youth: The impact of race on detention decisions. Journal of Research in Crime and Delinquency, 32(2), 149-165. 